\title{
STEAP1 expression in prostate cancer and its regulation by androgens
}

\author{
Inês Gomes ${ }^{1}$, Cecília RA Santos², Sílvia Socorro', Carlos Lopes², Cláudio J Maia ${ }^{1 *}$ \\ From 16th International Charles Heidelberger Symposium on Cancer Research \\ Coimbra, Portugal. 26-28 September 2010
}

Six transmembrane epithelial antigen of the prostate 1 (STEAP1) was identified a gene overexpressed in human prostate cancer. It is localized in cell junctions of epithelial cells, and its structure with six transmembrane domains suggests that it may act as a membrane channel or transporter protein in tight junctions [1]. Although STEAP1 expression seems to be up-regulated in prostate cancer, the clinical significance of this finding remains to be clarified. Moreover, STEAP1 is more expressed in $\mathrm{LNCaP}$ than in $\mathrm{PC} 3$, suggesting that androgens may regulate its expression. Therefore, the goals of this experimental work were: i) to evaluate if STEAP1 expression correlates with clinical reports from patients; ii) to analyze if STEAP1 is regulated by $5 \alpha$-dihydrotestosterone (DHT) in vitro and in vivo.

Immunohistochemical analysis shows that STEAP1 expression is mainly expressed in epithelial cells. Analysis of STEAP1 immunoreactivity in prostate cancer is underway. In vivo results demonstrated that castration increases STEAP1 protein expression when compared to intact rats, and treatment with DHT abrogates the effect of castration in STEAP1 expression, suggesting that STEAP1 protein is down-regulated by DHT. However, these results do not correlate with STEAP1 mRNA expression, suggesting that mechanisms at the translation level may be involved. In vitro results demonstrated that both STEAP1 mRNA and protein expression are down-regulated by DHT after $24 \mathrm{~h}$ of stimulation.

\section{Author details}

${ }^{1} \mathrm{CICS}-$ Health Sciences Research Centre, University of Beira Interior, Covilhã, Portugal. ${ }^{2}$ CBAS- Institute of Biomedical Sciences Abel Salazar, University of Porto, Porto, Portugal.

\footnotetext{
* Correspondence: cmaia@fcsaude.ubi.pt

${ }^{1}$ CICS-Health Sciences Research Centre, University of Beira Interior, Covilhã, Portugal

Full list of author information is available at the end of the article
}

Published: 24 September 2010

Reference

1. Hubert RS, Vivanco I, Chen E, Rastegar S, Leong K, Mitchell SC, Madraswala R, Zhou Y, Kuo J, Raitano AB, Jakobovits A, Saffran DC, Afar DE: STEAP: a prostate-specific cell-surface antigen highly expressed in human prostate tumors. Proc Natl Acad Sci U S A 1999, 96:14523-14528.

doi:10.1073/pnas.96.25.14523

Cite this article as: Gomes et al:: STEAP1 expression in prostate cancer and its regulation by androgens. BMC Proceedings 2010 4(Suppl 2):P63.
Submit your next manuscript to BioMed Central and take full advantage of:

- Convenient online submission

- Thorough peer review

- No space constraints or color figure charges

- Immediate publication on acceptance

- Inclusion in PubMed, CAS, Scopus and Google Scholar

- Research which is freely available for redistribution

Submit your manuscript at www.biomedcentral.com/submit
C Biomed Central 